\title{
STATE CANDIDACY: REQUIREMENTS, RIGHTS AND REMEDIES
}

The Voting Rights Act of $1965^{1}$ has elaborate provisions protecting the right to register and vote; ${ }^{2}$ however, it contains no specific provision protecting the right to be a candidate, free from discrimination. Yet discrimination at either level is equally effective in controlling the outcome of an election, ${ }^{3}$ and state procedures which create discrimination at the candidacy level can serve as a severe threat to a fair electoral process.

Twelve days before its 1966 election day, Mississippi enacted legislation requiring all candidates for the position of trustee of schools to file, at least ten days before the election, certain petitions and affidavits with the county superintendent of education. ${ }^{4}$ Thus, a potential candidate had only two days to obtain notice of the altered requirements and to comply with them. ${ }^{5}$ In Boyd $v$. Johnson, ${ }^{6}$ the District Court for Mississippi on petition of candidates who could not comply with the time limits of the statute, issued an order temporarily restraining enforcement of the act.

At the outset, it must be noted that under current law, there is no federal right to state candidacy. ${ }^{7}$ Nonetheless, states provide a

142 U.S.C. § 1973-1973p (1965).

2 The sanctions include the imposition of federal examiners, 42 U.S.C. $\$ 1973 \mathrm{a}$ (a), suspension of tests, 42 U.S.C. $\$ 1973 \mathrm{a}(\mathrm{b})$, and retention of equity jurisdiction over the offending state, 42 U.S.C. $\$ 1973 a(c)$.

3 Discrimination in the right to vote results in the disfavored class being unable to cast ballots for candidates sympathetic to it Discrimination in candidacy may result in the disfavored class, although possessing the vote, having no candidates sympathetic to it for whom to vote.

4 Section 6328-09 of the Mississippi Code was amended to read:

Any person otherwise eligible under the provisions of Section 6328-09, as amended, who shall desire to be a candidate for the office of trustee must qualify in the following manner in order to be allowed to be considered for election: At least ten (10) days before the election he shall file with the office of the county superintendent of education a petition signed by not less than twenty-five (25) qualified electors of the area represented by the office which he seeks . . and an affidavit by the candidate offering for election stating his qualifications under the terms of Section 6328-07, as amended. The petition shall contain an affidavit certifying that all signatures are the personal signatures of each person whose name appears on the petition and that each person is a qualified elector. . .

Unless the petition and affidavit required above shall be filed not less than ten (10) days prior to the election, the name of the candidate shall not be considered in the election, and votes cast for any person who has failed to qualify shall not be counted in the election.

Miss. Code ANN. $\$ 6328-09$ (Supp. 1966).

5 The act was signed by the governor on February 22, 1966, and took effect immediately. The next scheduled election was on March 5, 1966. Moreover, February 22 was a legal holiday, leaving only February 23 on which to qualify as a candidate. Boyd v. Johnson, Civil No. DC668 (D. Miss., March 2, 1966).

6 Civil No. DC668 (D. Miss., March 2, 1966).

7 Snowden v. Hughes, 321 U.S. 1, 7 (1943):

The right to become a candidate for state office, like the right to vote for the election of state officers . . . is a right or privilege of state citizenship, not 
privilege of becoming a candidate, and this privilege grows into a right when the state's candidate qualification procedures are met. For a state to deny a candidate the chance to ripen his privilege into a right by requiring him to fulfill conditions or comply with procedures that are unreasonable and arbitrary is violative of due process. ${ }^{8}$

Candidacy qualification statutes, in general, implement two valid state interests. The state may be concerned that candidates be substantively qualified ${ }^{9}$ and that there be a sufficient minimum time for administrative determination of candidate qualification to insure that the election can take place on schedule. ${ }^{10}$ Ordinarily the time of passage and the date of qualification are matters for the legislature's discretion. In some cases, however, the time available for candidate compliance resulting from the sudden passage of a new statute, such as the one in Boyd, will be so short as to cause hardship by minimizing the candidate's reasonable chances to comply.11 Once the candidate has established hardship, due process requires the state to provide justification for the statutory scheme. Because a fair electoral process

of national citizenship which alone is protected by the privileges and immunities clause.

It should be noted, however, that the increasing willingness of the court to protect the electoral process, see, e.g., Baker v. Carr, 369 U.S. 186 (1962) may make Snowden's continued viability questionable. See note 17 infra.

8 This reasoning recalls Griffin v. Illinois, 351 U.S. 12 (1954), where the Court held that, although a state was not required to provide for criminal appeals, once the process had been made available, it cotuld not be deprived arbitrarily. Griffin involved an equal protection argument, which reasoned that to deny indigents a trial transcript because they could not afford to buy one placed them in an arbitrary classification. At its roots, the due process argument in a candidacy case involves aspects of equal protection, for if it is established that the statutory time period is "unreasonable," the candidates who do and who do not qualify must by definition be separated by an irrationally drawn line. See also text accompanying note 14 infra.

9.Cf. MacDougall v. Green, 335 U.S. 281, 283 (1948). "It is allowable State policy to require that candidates for statewide office should have support not limited to a concentrated locality." Among the substantive requirements which might be imposed by the state on candidates are residency within the district, age and a petition showing that the candidate has the backing of a minimal number of voters.

10 Cf. Griffin v. Illinois, 351 U.S. 12, 21 (1956) (concurring opinion of Mr. Justice Frankfurter).

Nor does the equal protection of the laws deny a state the right to make classifications in law when such classifications are rooted in reason. . . The States have exercised this discriminating power. . . The different States and the same State from time to time have conditioned criminal appeals by fixing the time within which an appeal may be taken by delimiting the scope of review, by shaping the mechanism by which alleged errors may be brought before the appellate tribunal, and so forth.

Id. at 21 (emphasis added).

11 The determination of what is a reasonable time for compliance is factual. See Ring v. Marsh, 78 F. Supp. 914 (D.N.J. 1948) (twenty-two days is not arbitrary). The time in which the candidate can act to comply is conditioned by when he receives or should have received notice of the statutory change. Furthermore, it is necessary to consider exactly what the candidate must do in the time remaining. Thus while collecting twenty-five signatures of qualified electors, with an affidavit as to validity and an affidavit as to the candidate's personal qualifications, see note 4 supra, may be an unattainable goal if required in two days-or realistically, one day, see note 5 supra-the same requirements may not be unduly burdensome for a somewhat longer period. Likewise, lesser requirements, e.g. two signatures, uncertified, might not be burdensome, even with a one day time span. 
is an indispensable basis for political rights, the state should be required to show that the time period chosen is a reasonably necessary prerequisite-not merely a rational one-for the fulfillment of the legislative goals.

Mere legislative preference for one rather than another means for combating substantive evils . . . may well prove an inadequate foundation on which to rest regulations which are aimed at or in their operation diminish effective exercise of rights so necessary to the maintenance of democratic institutions. $^{12}$

As a practical matter, the due process determination in the candidacy case involves a balancing process. The court must weigh the state's need for the legislation against the threat to the plaintiff's candidacy. Because plaintiff's candidacy is an aspect of the overriding concern for fair electoral processes, his injury must be weighed more heavily than were he asserting merely an individual economic interest. ${ }^{13}$ Moreover, lurking in the background is the possibility of a discriminatory purpose on the part of the legislature. If potential candidates who are favored by the legislature are secretly informed in advance of the impending change, the headstart, coupled with the short time period, may as a practical matter restrict qualification for candidacy to them. Similarly, because an election official can refuse to provide the statutory information, he alone is able to determine who may and who may not qualify, simply because the time period is so short. ${ }^{14}$ Although it will be quite difficult, and perhaps impossible, to present sufficient evidence to sustain an equal protection claim, the potential for discrimination should be considered in the balancing process. As a result, evidence of a history of discrimination in the electoral process in the state, or even of entrenched one-party rule, the preservation of which could be a logical aim of the legislative action, is relevant.

Finally, of the two legitimate state interests in candidacy statutes, namely, substantive qualification and adequate time for the election process, only the latter is served by late passage of the statute. ${ }^{15}$ The state ordinarily could be expected to have passed the new statute earlier, or postponed the election date, if it felt the new substantive qualifications sufficiently compelling. The remaining state interest, which is one of administrative convenience, is made necessary by the state's own actions. As an administrative justification, it accordingly should be given less deference than would be given to a substantive state interest.

12 Thornhill v. Alabama, 310 U.S. 88, 95-96 (1940).

13 See United States v. Carolene Products Co., 304 U.S. 144, 152 n.4 (1938).

14 Cf. Louisiana v. United States, 380 U.S. 145 (1965) ; Niemotko v. Maryland, 340 U.S. 268 (1951).

15 Although a time deadline often does serve as a substantive qualifier, since it eliminates frivolous candidates, this aim can be fulfilled adequately by a time limit which does not work hardship on those who seriously wish to qualify. 
Therefore, if the hardship which potential candidates will undergo is not to be held unreasonable, the state must be able to justify affirmatively its timing of the statutory change.

Once it is established that a constitutional violation has occurred, the problem becomes one of fashioning a remedy. The availability of federal equity power to enjoin or otherwise interfere with a state election is no longer an issue. Baker $v$. Carr ${ }^{16}$ has removed any suspicion that the fourteenth amendment claim is non-justiciable ${ }^{17}$ and justiciability necessarily includes the power to grant equitable relief. ${ }^{18}$ However, the threshold determination of justiciability does not determine whether a particular kind of equitable relief-or indeed any equitable relief-is appropriate. ${ }^{19}$

Determination of a constitutional violation in candidacy cases requires a fourteenth amendment balance, involving a weighing of the state's justification against the harm to the candidate resulting from the statutory scheme. Having found a due process violation, the court is sitting in equity to determine relief, and different interests must be weighed. Plaintiff's interest remains constant no matter what form of relief is chosen: he desires only to qualify as a candidate, and can demand only that he be put in status quo ante. The state's interest, however, now comprehends a variable factor: the degree of disruption of its election process. ${ }^{20}$ The Fifth Circuit has held that withholding injunctive relief in spite of an equal protection violation of election process is not justified a priori, stating that:

16369 U.S. 186 (1962).

17 Baker, of course, decided the issue in the context of legislative reapportionment. The Court held that the question of the apportionment of a state legislature presented a claim justiciable in the federal courts; that is, there was a duty which could be judicially identified, a breach of which could be determined and protections for the right asserted could be judicially molded. 369 U.S. at 198. It also noted that, if discrimination were shown, the right to relief under the equal protection clause would not be diminished by the fact that the discrimination related to state political rights. Id. at 210 (quoting Snowden v. Hughes, 321 U.S. 1, 11 (1943)) (Court would have reached the merits had the plaintiff alleged an "invidious or purposeful" discrimination in a state official's failure to certify him as a candidate).

18 Even after Baker, however, the notion of justiciability as the power to grant relief was still not fully accepted. In Wesberry v. Vandiver, $206 \mathrm{~F}$. Supp. 276, 285-86 (N.D. Ga. 1962), rev'd sub nom., Wesberry v. Sanders, 376 U.S. 1. (1964), the district court held that the question of the apportionment of the Georgia legislature presented a justiciable issue, but nevertheless dismissed the case for "want of equity," asserting that the plaintiff must look to the legislature for relief. Judge Brown, in Bush v. Martin, 224 F. Supp. 499, 512-13 (S.D. Texas 1963), aff'd, 376 U.S. 222 (1964) analyzed into absurdity the Wesberry district court's assertion that although there may be a justiciable question, the court must dismiss for want of equity: "When that Court as a whole recognized, as it does, that the discrimination in Georgia was 'egregious' and yet the Court is powerless to do anything about it, it is to us the old shibboleth of non-justiciability in a new cloak." Id. at 512. See Wesberry v. Sanders, 376 U.S. 1, 4 (1964); Wesberry v. Vandiver, 206 F. Supp. 276, 286-87 (N.D. Ga. 1962) (concurring and dissenting opinion).

1s See MacDougall v. Green, 335 U.S. 281, $285-86$ (1948) (Rutledge, J., concurring).

20 Compare Hamer v. Campbell, 358 F.2d 215, 222 n.20 (5th Cir.), cert. denied, 385 U.S. 851 (1966), with Mr. Justice Rutledge's concurrence in the pre-Baker case of MacDougall v. Green, 335 U.S. 281, 284 (1948). 
To be sure, the Supreme Court in Reynolds v. Sims ${ }^{21}$. . . has held that in some cases it might be proper not to enjoin an election to be conducted pursuant to an unconstitutional plan. But appellees' reliance on these cases is misplaced. The shoe will not fit. First, the Court clearly warned that it "would be the unusual case in which a court would be justified in not taking appropriate action to insure that no further elections are conducted under the invalid plan. Second, the reapportionment cases deal with dilution of the vote. This case involves a deprivation. Third, in the reapportionment cases the Court is dealing with a legislative function. Staying judicial relief may give the State a chance to clean its own house and thus avoid a court-imposed, nonlegislative disruption of its election process. In effect, the substantive relief ordained by the court is to come from action by the legislature. Hence a court may properly withhold injunctive relief in order to allow the State to remedy dilution of the franchise. But the municipal bodies involved in these elections have no power to eradicate the deprivation of the franchise. Relief, if it is to be had, must perforce come from the Court or the voters must simply be told to wait four more years. That denial of this fundamental Right cannot be justified in the name of equity. ${ }^{22}$

Any duty of the court to grant relief, however, does not derogate from the court's responsibility to mitigate unnecessary disturbance of the state's election process. One potential source of disruption is the delay connected with the ordinary course of court procedure. The usual injunction suit alleging discriminatory interference with the election process, e.g., discrimination against the private voter under the Civil Rights Acts, ${ }^{23}$ is heard and determined in the district court, with appeal to the circuit court, ${ }^{24}$ and thence to the Supreme Court. ${ }^{25}$ This is to be contrasted with the machinery triggered by a challenge to the belated candidacy statute. The latter is a request for an "injunction restraining the enforcement, operation or execution of [a] State statute." It is therefore governed by 28 U.S.C. $\S 2281$, which requires a hearing before a three judge federal district court, ${ }^{26}$ al-

21377 U.S. 533 (1964).

22358 F.2d at $221-22$. Note that the candidacy case also involves a "deprivation," not a "dilution." See note 3 supra.

2342 U.S.C. $\$ \$ 1971,1973,1981,1983,1985$ (1965) ; 28 U.S.C. $\$ 1343(3)-(4)$ (1964). See, e.g., Bell v. Southwell, 376 F.2d 659 (5th Cir. 1967); Hamer v. Campbell, 358 F.2d 215 (5th Cir.), cert. denied, 385 U.S. 851 (1966); McGill v. Ryals, 385 U.S. 19 (1966) (per curiam), dismissing appeal from 253 F. Supp. 374 (M.D. Ala. 1966) ("The appeal is dismissed for want of jurisdiction because the case was not appropriate for a three-judge court.")

2428 U.S.C. \&1291 (1964).

2528 U.S.C. \$ 1254 (1964).

26 To be convened under 28 U.S.C. $\$ 2284$ (1964), 
though a temporary restraining order may be granted by a district judge to prevent irreparable damage. ${ }^{27}$ After five days' notice to the state, ${ }^{28}$ the request for injunction must be heard by the three judge court at the earliest practicable time. ${ }^{29}$ Thus, the extant accelerated hearing procedure, by-passing the ordinary docket delay, ${ }^{30}$ as well as eliminating the intermediate appeal to the Court of Appeals, minimizes at the outset the electoral disruption caused by delay in the judicial process. ${ }^{31}$

Remedies in this area fit into two broad categories: a request that the court interfere with an election soon to be held under the unconstitutional statute, and a suit to order invalidation of an election which has already taken place. The plaintiff who does not file until after election day may be vulnerable to a defense of laches. If an election is invalidated, the state will be subject to the greatest disruption which judicial intervention can work. With reasonable diligence in applying to the court before the election date, plaintiff could have minimized the chances that the only relief adequate to undo the fourteenth amendment violation would be overturning the election. In the only case factually in point, the court refused to vacate an admittedly defective election, implying a requirement that a plaintiff apply for relief before election day. ${ }^{32}$

27 In any such case in which an application for an interlocutory injunction is made, the district judge to whom the application is made may, at any time, grant a temporary restraining order to prevent irreparable damage. The order, unless previously revoked by the district judge, shall remain in force only until the hearing and determination by the full court. It shall contain a specific finding, based upon evidence submitted to such judge and identified by reference thereto, that specified irreparable damage will result if the order is not granted.

28 U.S.C. \$2284(3) (1964).

28 If the action involves the enforcement, operation or execution of State statutes or State administrative orders, at least five days' notice of the hearing shall be given to the governor and attorney general of the State.

28 U.S.C. \$2284(2) (1964).

29 In any such case the application shall be given precedence and assigned for a hearing at the earliest practicable day. Two judges must concur in granting the application.

28 U.S.C. \$2284(4) (1964).

30 In the suit not governed by 28 U.S.C. $\$ 2281$ (1964), an expedited appeal seems to be available, outside of statutory mandate, in the discretion of the court of appeals. See Hamer v. Campbell, 358 F.2d 215, 222 (5th Cir.), cert. denied, 385 U.S. 851 (1966).

31 Note, however, that there is no accelerated appeals procedure from the threejudge district court to the Supreme Court. Compare 28 U.S.C. $\$ 1253$ (1964) with 28 U.S.C. $\$ 2102$ (1964), giving priority on the docket to appeals from state criminal proceedings and suits in which the United States is a party. Nevertheless, if the court determines that the case is one of public importance, it would seem within its discretion to grant it priority. Cf. Ray v. Blair, 343 U.S. 154 (1952). But cf. Shub v. Simpson, 340 U.S. 861 (1950).

32 McGill v. Ryals, 253 F. Supp. 374 (M.D. Ala.), appeal dismissed, 385 U.S. 19 (1966) (per curiam) in which "elections which occurred, in some instances, nearly six years ago," $i d$. at 377 , were challenged on grounds of voter registration discrimination. The court's statement of the laches rule was that the community's "substantial interest in stable elections and the prompt determination of their validity," id. at 376, should prevent relief when the delay in contesting the election is attributable solely to the plaintiff. "Had resort been made to the courts at these earlier dates, the 
Although some dislocation is inevitable, the state should be protected from meretricious suits, and preconditions to plaintiff's suit other than timeliness are justified if they do not undercut the effectiveness of the challenge. Plaintiff should be required to show that he could have complied with the old candidacy requirements (of which he had ample notice) ${ }^{33}$ and with the new legislative dictate (but for the tardiness in passing the statute). The requirement of individual compliance makes a class action inappropriate because candidates will not be similarly situated..$^{34}$ Relief which can be fashioned so as to apply to, e.g., only one office or one county, would apply where no injury has been shown, and the attractiveness and utility of harassment suits would be minimized. ${ }^{35}$

Besides pre-screening the plaintiffs and defining permissible suits, proper deference by the federal court to the state's interest extends to choice of remedies for the unconstitutionally timed statute. There are two general kinds of pre-election relief. The first is an order directing that the election be held as scheduled, with the candidate being allowed to qualify under the requirements that had served in the past. The new statute would only be held inoperative for one election, since in succeeding years there would be ample warning of the change. This is a variation of the "freezing" technique developed in voter registration cases in the Fifth Circuit. ${ }^{36}$

Alternatively, there is the order postponing the qualifying date so that the applicant has sufficient time to qualify under the newand substantively proper-candidacy requirements. In some situations, this remedy may require the state to delay the election in order to have adequate time to prepare after the qualifying date.

In deciding between the two remedies, two state concerns should be considered. The candidate for public office should be substantively qualified, and the election process should not be disrupted through delay. Each of the remedies furthers one of the interests, but only at

wrongs complained of could not have accumulated to the extent that they have." Id. In its long list of reasons for denying relief, the court does not clearly indicate the weight carried by plaintiff's delay. See 52 IowA L. REv. 564, 569 (1966). However, the Fifth Circuit seems to have approved of the laches rule in distinguishing McGill from a case in which it was chronologically impossible to challenge the discrimination before the election since it took place at the polls. See Bell v. Southwell, 376 F. 2d $659,663,664$ (5th Cir. 1967). See also Hamer v. Campbell, 358 F.2d 215, 222 (5th Cir.), cert. denied, 385 U.S. 851 (1966).

33 The proof required to show that the candidate "could have complied" is a problem which is beyond the scope of this Comment.

34 See FED. R. Crv. P. 23(a) (2), (a) (3).

35 These objections, of course, do not apply to consolidations of individual suits. 36 See United States v. Ward, 349 F.2d 795 (5th Cir. 1965) ; United States v. Lynd, 349 F.2d 785 (5th Cir. 1965); United States v. Duke, 332 F.2d 759 (5th Cir. 1964) ; Note, Freezing Voter Qualifications to Aid Negro Registration, 63 MICn. L. REv. 932 (1965) ; cf. United States v. Dogan, 314 F.2d 767 (5th Cir. 1953) (payment of overdue poll taxes munc pro tumc to remedy discrimination); United States v. Alabama, 192 F. Supp. 677 (M.D. Ala. 1961), aff'd, 304 F.2d 583 (5th Cir.), aff'd per curiam, 371 U.S. 37 (1962); 42 U.S.C. \$1973a(b) (1965) (incorporating the Alabama rule). 
the expense of the other. It will be recalled that the interest of the plaintiff-candidate is irrelevant in determining which mode of relief to grant. He has no vested interest in any particular set of statutory terms, so long as the requirements that are in force are fair in themselves and are imposed with a reasonable time in which to comply. Ideally, then, the state, by its attorney-general, should be permitted to take its choice between substantive modification of the requirements or delay in the process. When the claim is determined by the three-judge court before substantial interruption of the electoral sequence, the state's attorney is able to exercise his judgment.

Determining relief by reference to pre-election and post-election equities, however, may frequently be realistically impossible. Precipitous changes in statutory candidacy requirements are only burdensome when close to the qualifying date, ${ }^{37}$ which is usually just before the election. Thus, the court procedure, from application for the temporary restraining order to final disposition by the three-judge court, is likely to straddle the election date, timely application by plaintiff notwithstanding. The choice between the freeze or judicial postponement of the qualifying date will have to be made at the hearing on the restraining order (assuming the injunction is to issue at all), in order for either of the remedies to work; once the election has taken place, the only effective relief is a drastic order overturning the election. The choice between remedies, ideally left with the state attorneygeneral, will of necessity be determined by the district judge at an ex parte hearing. That judge's choice being non-reviewable by the three-judge court (it having been hypothesized that the election has already taken place), and there being no state delegate to elect between alternatives in which plaintiff has no proper interest, the judge must make an $a$ priori choice between the state's interest in the substantive qualifications and timely election procedure.

The problem of choosing between delaying the qualifying date and freezing the qualification requirements is dwarfed by the decision of whether to issue the temporary restraining order at all. That will determine plaintiff's participation vel non in the intervening election, while decision on the merits of the constitutional claim will await the three-judge court. If the district judge denies relief to the candidate who later prevails under the fourteenth amendment, the threejudge court is left with the alternatives of overturning the election, or denying relief for the constitutional violation on grounds that the relief is too disruptive. If the latter were to occur, then the district judge himself has effectively exercised the power-without ever having reached the merits-to foreclose all constitutional redress in an ex parte hearing.

Two decisions in the Fifth Circuit on voter discrimination, however, suggest that, absent plaintiff laches, the drastic solution of in-

$\mathbf{8 7}$ Or alternatively, if the qualifying date itself is changed without notice. 
validating the election is proper. In Hamer $v$. Campbell, ${ }^{38}$ the court of appeals set aside a local election because of discrimination in voter registration, ${ }^{39}$ although the trial court refused to enjoin the election which thus erroneously took place under the district court's sanction. ${ }^{40}$ The precedent is somewhat weakened, however, by the fact that the state opposed an expedited appeal which could have been heard prior to the election. In so doing, it conceded that when the appeal was heard, the plaintiff, if successful, would be entitled to all relief which otherwise would have been granted. ${ }^{41}$ In Bell $v$. Southwell, ${ }^{42}$ the discrimination took place at the polls on election day, so that both district and appellate court rulings followed the election. The Fifth Circuit held that Hamer was precedent for overturning the election, without mentioning the state's stipulation there. In combination, then, Hamer and Bell suggest that invocation of the remedy of invalidation depends on the unavailability of preventive relief. And in the present context, unavailability is equivalent to denial of the restraining order. ${ }^{43}$

Problems also will arise when a candidate, who later loses his constitutional claim on the merits, has been qualified for the election which has taken place in the interim. It can be argued that if the candidate loses the election, he may be mathematically immaterial to the outcome, so that the state's case is mooted. ${ }^{44}$ If plaintiff has attracted a vote sufficient to alter the outcome when added to another's tally, or indeed

38358 F.2d 215 (5th Cir.), cert. denied, 385 U.S. 851 (1966).

39 Qualification as an elector was also a precondition to qualification as a candidate. Id. at 218 . However, the only plaintiff-candidate had qualified as an elector and was therefore held incapable of maintaining suit, $i d$. at 219 , and the action is properly called a registration case.

40 As the case did not involve restraint of a state statute on the ground of unconstitutionality, the decisions that straddled the election were those of the district and appellate courts, rather than those of the restraining order judge and the threejudge trial court. The fact that the system is accustomed to reversing lower courts for errors of law may at first make Hamer an easier case for upsetting an election than the last-minute candidacy statute situation; in the latter, the pre-election hearing is on the issuance vel non of a temporary restraining order, which theoretically is totally discretionary. When a request for the order is denied, the posture of the case is not whether the election should have been enjoined, but whether it should now be overturned.

However, the restraining order is really no more than an available device for avoiding unnecessary injury. It is not the disposition of the case, but a discretionary measure for insuring that victory in the case not be pyrrhic because of injury sustained in the interim. Thus, a decision by the district judge that the order should not be granted, viewed from the post-election point of view, puts the plaintiff in the same position as if the remedy of an interim restraining order had never been available -and only post-election relief is obtainable. When the temporary order is considered in this light, the case becomes indistinguishable from Bell v. Southworth, 376 F.2d 659 (5th Cir. 1967), where, since violations occurred at the polls, the election had to be overturned or the plaintiffs would have been left with no remedy at any point in time.

41358 F.2d at 222 .

42376 F.2d 659 (5th Cir. 1967).

43 See note 40 supra.

44 If another candidate has received a statutory majority of the votes, then the votes cast for the plaintiff-candidate are immaterial to the outcome. No matter for what other candidate those votes might have been cast, the result of the election would be the same. 
has won the election himself, state procedures exist for dealing with a candidate who is found to be disqualified after election day. Nonetheless, some unfairness to the state and the other candidates may result. ${ }^{45}$

Perhaps, the best solution of the straddle conundrum is the most simple. It will be remembered that one of the two forms of pre-election relief was postponement of the candidacy qualification date. If, instead, the election itself were postponed until the three-judge court determination, the straddle effect would be totally avoided. ${ }^{46}$ The function of the district judge would be merely to restrain the election temporarily, and a rule could be established that whenever plaintiff's ex parte claim was colorable, the order should be granted.

The unreducible danger, of course, is the potential for harassment in postponing state elections at plaintiff's whim. Moreover, if the local election is tied in with a statewide or national election, postponement of the election may prove totally impracticable. ${ }^{47}$

45 Although state legislatures have made provision for contesting elections when the qualifications of reinning candidates are challenged, no such provision has been made to allow contests when the qualifications of losing candidates are questioned, suggesting a legislative judgment that the evils of disruption are more severe than the benefits of a one-hundred per cent certified victor. See, e.g., ALA. Cone tit. 17, $\$ \$ 231-35$ (1959); cf. La. Rev. Stat. AnN. \$18-1251 (1951); Miss. Code ANN. $\S 3287$ (1957).

${ }_{46}$ Cf. Hamer v. Campbell, 358 F.2d 215 (5th Cir.), cert. denied, 385 U.S. 851 (1966), where the court held that the district const, after its hearing on the merits, should have enjoined the municipal election, under a complaint which

sought a judgment: (1) delaying the municipal elections and fixing new dates therefor, (2) fixing a new cutoff date for voter registration for the delayed elections, (3) fixing a new cutoff date for qualification of candidates, and (4) suspending the requirement that poll taxes shall be paid as a prerequisite to voting, or, in the alternative, allowing munc pro thinc payment of 1963 and 1964 poll taxes.

Id. at 218. The Court noted that:

Although it would have been possible merely to fix new cutoff dates for registration, qualification of candidates, and payment of poll taxes prior to the elections as originally scheduled, the District Court had ample basis for presumably believing that the short time between the filing of this suit and the scheduled primaries made this impractical. The Court undoubtedly assumed that for the other relief sought $(2-4)$ to be effective, it would be imperative that the elections be postponed.

$I d$. at 218 n.6. Although the only plaintiff-candidate was held to have no standing, see note 39 supra, the holding seems to contemplate postponement of election date as well as qualification date had a proper plaintiff-candidate required it.

$47 \mathrm{Cf}$. the language of $\mathrm{Mr}$. Justice Rutledge, in MacDougall v. Green, 335 U.S. 281, 286-87 (1948) (concurring opinion) :

We are on the eve of the national election. But twelve days remain. The ballots, as certified by the state officials, are in [the] process of printing and distribution. Absentee ballots have been distributed. Illinois is one of the more populous states. Millions of ballots will be required, not only in the state but in Cook County alone. . . The task would be gigantic. Even with the mobilization of every possible resource, it is gravely doubtful that it could be accomplished. The risk would be very large that it could not be done. Even if it could for all except absentee voters, they would be disfranchised. Issuance of the injunction sought would invalidate the ballots already prepared, including the absentee ballots and those now in course of preparation.

The sum of these considerations . . . forces me to conclude that the relief sought could be had at this late stage in the electoral process only at the gravest risk of disrupting that process completely in Illinois or of disfranchising Illinois voters in perhaps much greater numbers than those whose interests appellants represent. 
In any case, where invalidating the election becomes necessary, existing state procedures probably can be utilized to minimize the consequent disruption. Because of the accelerated hearing provided for under 28 U.S.C. $\$ 2284$, most hearings on the constitutionality of lastminute candidacy statutes can be had within the "lame duck" period, prior to the transfer of power from the incumbents to their successors. If a new election can be scheduled before the date set for transfer of power, there need be no disruption in the orderly continuity of governmental functions. But if it is not practical to hold the new election during the "lame duck" period, disruption can still be minimized in those states having statutory provisions to the effect that incumbent officials shall hold office for a prescribed period, or until their successors are seated. ${ }^{48}$ Since the election under the unconstitutional candidacy statute is void, those elected in it have no claim to office and are therefore not successors. The old incumbents may continue to govern until a valid election is held. Since the incumbents remain in office pursuant to the statutorily prescribed tenure, there is no question as to the validity of their official acts during the interim period.

Other problems arise if the validity of the challenged election cannot be determined until after the expiration of the "lame duck" period. In this situation, since the election is presumed valid until found otherwise, those elected will have assumed power and begun its exercise, only to have their right to hold office found wanting by the court. Under the statutory doctrine of the validity of the acts of de facto government officials, the acts of those elected in the invalidated election cannot be challenged on the ground of their failure to hold office rightfully. ${ }^{49}$ The question remains, however, as to who shall govern, pending the holding of a new election and the seating of successors. The least disruptive solution would be to let the invalidly elected officials continue in power for the interim. This was the solution adopted in Hamer v. Campbell. It has the added advantage of minimizing disruption, if the new court-ordered election results in the ascendance of the same candidates who were elected in the invalid election.

Alternatively, the decree invalidating the election can declare the offices vacant, thereby activating state statutes for the temporary filling of vacant offices. These statutes provide that when an office becomes vacant, it may be filled by a temporary appointment on the part of some government executive. ${ }^{50}$ The appointee serves until his successor is elected and seated.

48 See, e.g., ALA. CODE tit. 41, \$\$15-19 (1959); LA. Rev. STAT. ANN. §42-2 (1965); Mrss. CoDE ANN. \$4026 (1957).

49 See, e.g., Ala. Code tit. 41, §2 (1959); cf. Miss. Code ANn. $\$ 4045$ (1957).

50 See, e.g., Ala. Code tit. 41, \$\$160-77 (1959); cf. LA. Rev. Stat. ANN. \$\$ 42-371 to -373 (1965); MISS. CODE ANN. $\$ \$ 3291-96$ (1957), both providing that some offices are to be filled by election, and the more local ones by appointment. 